\section{Espaços migratórios e problemática ambiental no Mercosul}

\author{
José Marcos Pinto da Cunha* \\ Sylvain Souchaud ${ }^{\star \star}$ \\ Rosana Baeninger ${ }^{*}$ \\ Roberto Luiz do Carmo*
}

O projeto "Espaços migratórios e problemática ambiental no Mercosul" é de cooperação Brasil-França, entre o CNPq e o Institut de Recherche pour le Développement (IRD), desenvolvido pelo Núcleo de Estudos de População (Nepo) da Unicamp e o Laboratoire Population Environnement Développement (LPED-IRD). Trata-se do estudo das migrações entre o Brasil e os países vizinhos do Mercosul, com destaque para Bolívia, Paraguai e Argentina. O objetivo é evidenciar situações diferenciadas e complexas entre esses países e fomentar a comparação dos diferentes espaços migratórios, que estruturam partes da dinâmica socioespacial da região, possibilitando a meIhor compreensão de um fenômeno que vem ganhando importância nos últimos 20 anos.

Nesse contexto, consideram-se as dinâmicas espaciais das migrações, sua formação e evolução vis-à-vis as mudanças territoriais e ambientais que se observam no contexto da integração regional e mundial. Atenção privilegiada é dada às regiões de fronteiras entre os países, baseando-se na hipótese de que essas áreas articulam várias formas migratórias e são, portanto, laboratórios tanto da própria diversidade dos espaços migratórios como das modificações nas dinâmicas de organização do espaço que ocorrem no subcontinente.

A partir daí privilegiam-se na análise:

- a descrição da estruturação das migrações nos lugares de saída, de chegada e de trânsito, cujas relações, estabelecidas entre esses lugares pelos próprios migrantes, são constituintes da conformação de espaços migratórios reveladores de algumas transformações territoriais, tais como formação de novos eixos de circulação, integração de novos espaços e, ao mesmo tempo, concentração em alguns deles e organizados em "arquipélagos";

- o estudo dos impactos ambientais e migração, bem como suas percepções nas populações locais;

- a organização social dos migrantes, de maneira individual ou coletiva, suas trajetórias e estratégias a partir da identificação de percursos migratórios, redes de relações sociais, evolução e reprodução de uma geração para outra.

\section{Primeiros resultados}

Dada a variedade das migrações e espaços abrangidos pela proposta inicial, as primeiras análises (dados secundários censitários cartografados e visitas a campo) permitiram associar certas temáticas a estudos mais pontuais, por um lado, e estreitar as hipóteses, por outro.

Em um primeiro momento, até 2008, as análises estarão focalizadas nos intercâmbios migratórios entre Brasil, Paraguai e Bolívia, a partir da zona que se estende no Mato Grosso do Sul, Chaco paraguaio e extremo oriente da Bolívia. Este espaço interior articula diferentes correntes migratórias que assumem formas diversas quanto a duração, alcance e intensidade.

Este espaço migratório deu lugar a uma proposta de tipologia preliminar, que conta com quatro modalidades de migração: a fronteiriça de vizinhança recíproca; a fronteiriça unilateral; a urbana diversificada; e a metropolitana exclusiva. Desse modo, um conjunto de elementos sociais e espaciais permite identificações e comparações.

Com efeito, no que se refere às migrações bolivianas e paraguaias no Brasil, os

\footnotetext{
*Professores do IFCH/Unicamp e Pesquisadores do Nepo/Unicamp.

**Pesquisador do IRD-França.
} 
volumes parecem ser comparáveis. Contudo, a distribuição no espaço é nitidamente distinta e observa-se uma dispersão maior da comunidade boliviana em relação à paraguaia. As hipóteses que são exploradas para explicar essa diferença consideram, por exemplo, a antigüidade da migração, o fator de estruturação e a diversificação das redes migratórias. Além disso, verifica-se, nesses dois casos, uma diminuição da migração transfronteiriça, ou, pelo menos, uma concentração mais forte em alguns lugares caracterizados por sua forte acessibilidade, no caso as cidades de fronteira.

Ao mesmo tempo, têm-se algumas indicações que levam a pensar que os lugares de origem dos migrantes evoluem, sendo mais distantes geograficamente da fronteira. Desenvolvendo este elemento, a fronteira parece assumir, cada vez mais, o papel de espaço de trânsito, de intermediário, em circuitos migratórios mais amplos que unem pólos urbanos distantes, os quais a priori tecem poucos laços com os espaços de fronteiras.

Em conseqüência, a fronteira articularia, cada vez menos, as migrações de curto alcance (transfronteiriças). Nesse sentido, alguns focos da fronteira seriam mais integrados nas dinâmicas espaciais com maior abrangência do subcontinente; ou seja, a fronteira organiza migrações principalmente no caso do movimento com destino às grandes cidades ou metrópoles. As cidades de fronteira integram de maneira crescente os projetos migratórios, embora a zona de fronteira em seu conjunto (rural e urbano) o faça cada vez menos. São essas evoluções hipotéticas que tentamos descrever e analisar. Os mecanismos condicionantes podem ser vários, desde políticas migratórias até a organização de territórios e a circulação dentro deles.

Evidentemente, os espaços de trânsito emergentes nas fronteiras, que aparecem e se deslocam segundo oportunidades e, sobretudo, restrições à circulação dos migrantes internacionais, têm vocação a se tornarem espaços de chegada, para uma parte dos migrantes cujo projeto não se concretizou. Por exemplo, alguns migrantes bolivianos instalam-se em Corumbá provi- soriamente, à espera de uma oportunidade de passagem até São Paulo, e, eventualmente, adiam várias vezes a "re-emigração" até se instalarem de forma prolongada em Corumbá. Note-se que Corumbá oferece aos migrantes bolivianos um estatuto privilegiado, que favorece melhor inserção profissional e acesso a sistemas de saúde e educação. Mas, passados os limites da cidade, um controle drástico aparece. Então, Corumbá é, ao mesmo tempo, um lugar de trânsito, de refugio e de permanência.

Busca-se, portanto, identificar e analisar essas diferentes formas de migração e inserção no espaço (na cidade e no território nacional), associando-as às estratégias migratórias que favorecem a adaptação. As estratégias migratórias estabelecem-se em nível da formação e utilização de redes relacionais e de tipos de deslocamentos entre diferentes pontos do espaço migratório (circulação, vai-e-vem, residência-base, duração, freqüência).

A análise da migração brasileira, tanto no Paraguai como na Bolívia, permite colocar a questão ambiental no centro do estudo. Nos casos anteriormente evocados, a questão ambiental emerge não como preponderante, mas sim contextualmente e/ou como epifenômeno. Assim, os migrantes bolivianos e paraguaios não se assemelham à categoria de "refugiados do ambiente", uma das principais categorias que integram os estudos migração-ambiente. Por outro lado, os estoques de migrantes não são em número suficiente e tampouco assumem características específicas para que a eles se possa atribuir um impacto ambiental relevante. Principalmente urbanos, são poucos e não modificam de forma fundamental a dinâmica urbana. Quando são rurais (poucos casos) no local de destino, integram-se em atividades já existentes, como mão-de-obra, e não se pode razoavelmente estudar seus impactos ambientais (por exemplo, as conseqüências nos ecossistemas da implantação de sistemas produtivos).

A situação é diferente para os migrantes brasileiros que se implantam em ecossistemas frágeis e/ou com pouco antrópico, trazendo consigo sistemas produtivos que 
os modificam profundamente. Esse é o caso da monocultura intensiva da soja, no oriente do Paraguai ou na região de Santa Cruz de la Sierra (Bolívia oriental), ou ainda na criação semi-intensiva de gado nas reservas ecológicas do Chaco paraguaio. A imigração brasileira no Chaco paraguaio é ainda muito pouco conhecida em comparação àquela no oriente. Assim, torna-se importante pesquisar os impactos ambientais da migração brasileira sobre a organização das numerosas comunidades indígenas existentes no Chaco, atividade esta que será realizada com uma equipe de pesquisadores paraguaios. Uma das orientações é estudar como e com quais conseqüências o discurso sobre espoliação e reivindicação do direito à terra substituiu aquele referente à preservação ambiental.
O projeto, que começou em setembro de 2005 e terá duração de quatro anos, envolve demógrafos, antropólogos e geógrafos do Nepo e do LPED, contando, também, com apoio obtido através de convênios da "Asociación de Estúdios de población" (ADEPO) do Paraguai e do "Centro de Estúdios Avanzados" (CEA) da Universidade Nacional de Córdoba. Com isso, promovese uma cooperação regional sobre assuntos de interesse comum, como é a migração internacional. O material de pesquisa será proporcionado, principalmente, por trabalhos de campo, levantamentos domiciliares e entrevistas em profundidade, a serem realizados nos diversos espaços, - rurais ou urbanos - mencionados anteriormente.

Recebido para publicação em 26/05/2006. Aceito para publicação em 09/06/2006. 